\title{
Marek Butrym*
}

iD https://orcid.org/0000-0001-8550-3405

\section{THE INTERNATIONALISATION OF HIGHER EDUCATION: LOSSES AND BENEFITS}

\begin{abstract}
International declarations emphasise the role of higher education in building the knowledge society and underline its importance for the economic, social and cultural development of individual countries. The article shows how the internationalisation of higher education transforms universities, cities and countries that welcome international students. At the same time, it is stressed that the internationalisation of higher education and the employment of well-educated foreign students in the destination country is one of the forms of brain drain and competition for gifted young people. The example of Poland, where Ukrainian students dominate among international students, is used to demonstrate the benefits enjoyed by the destination country and losses suffered by the country of origin. The situation is presented against the backdrop of the current political instability in Ukraine, which may additionally encourage young people to study and settle abroad.

Keywords: internationalisation of higher education, international students, incoming students, post-graduation plans.
\end{abstract}

State Parties shall $[\ldots]$ make higher education accessible to all on the basis of capacity by every appropriate means.

(Convention on the Rights of the Child, 1989)

\section{Introduction}

In accordance with the 1989 UN Convention on the Rights of the Child, all states are obliged to provide equal conditions for obtaining higher education. The only criterion for access to higher education is the talents of young people. Thirty years after the adoption of this Convention, and following subsequent international declarations concerning higher education (Bologna 1999; Leuven 2009), taking into account student mobility among the young generation and growing interest in studying abroad, it is worthwhile to explore the intellectual and economic context of this phenomenon.

* PhD hab., Department of Sociology, Faculty of Social Sciences, University of Warmia and Mazury in Olsztyn, ul. Szrajbera 11, 10-007 Olsztyn, e-mail: marek.butrym@uwm.edu.pl 
The internationalisation of higher education has a long-standing tradition in many countries. It is estimated as the percentage of students coming from abroad from the total number of students in public and non-public higher education institutions in a given country. Universities are making efforts to increase the level of internationalisation, as it is one of the criteria for assessing academic centres, their scientific achievements, and the rating of universities in the country and beyond. In Europe, these processes were accelerated by the Bologna Declaration of June 19, 1999, which became the basis for continuous adjustment of higher education to changes and building the knowledge society which is conducive to the social, economic and cultural development of individual countries. To a large extent, this has become a challenge for universities, as the central role in building the knowledge society has been assigned to higher education institutions (the Bologna Declaration). The 2009 Leuven Conference of European Ministers Responsible for Higher Education made an assumption that "in 2020, at least 20\% of those graduating in the European Higher Education Area should have had a study or training period abroad" (Saryusz-Wolski, Piotrowska 2011: 44). It is recommended that students should study at a university abroad for at least a semester or a year.

Tertiary education plays a fundamental role in building the knowledge society. It aims at the development of "human capital", ${ }^{1}$ and, in particular, its essential, intangible component i.e. the "intellectual capital" obtained and developed by young people during their studies. As stressed by scholars, knowledge and acquired skills largely determine the socio-economic growth of countries and regions, because "it is not labour, commodities or capital that is the key resource, but knowledge that enables achieving competitiveness and high level of development" (Mendryk et al. 2020: 6).

Against this backdrop, let me analyse the role and importance of the internationalisation of higher education in achieving this objective. Let me also address the issue of student mobility across countries and universities, as well as the issue of who gains and who loses as a result of student mobility. The article aims to explore these questions. I sought the answers in a literature review, using key words such as internationalisation of higher education, international students, student migration, students from Ukraine in Poland.

\section{On the internationalisation processes}

Internationalisation was typical of the first European medieval universities, which makes it clear that this idea did not emerge in the first decade of the $21 \mathrm{st}$ century (Bergen 2011) and was known in previous centuries and years. How-

${ }^{1}$ Human capital is understood, among other things, as the renewable human potential that can be developed. It encompasses measurable individual resources of knowledge, skills, abilities, qualifications, attitudes and motivation which can be used for the development of individuals, larger communities and society as a whole (cf. Łukasiewicz 2009). 
ever, the last decades have seen a growing interest in studying abroad. For some time now, internationalisation has been promoted by the universities in the United States, Canada, the UK and Australia. For young people from different countries seeking opportunities to study abroad, the extent of internationalisation is indicative of the experience that a university has, and the level of education offered. It also guarantees that the diplomas obtained from internationalised universities increase one's employability in one's home country as well as the international labour market. For many students, this is also an opportunity to obtain a prestigious diploma which offers opportunities for further in-depth scientific specialisation. From the perspective of the young generation, studying abroad can be seen as a career path and an opportunity for social advancement.

The internationalisation of higher education is coupled with the increasing global mobility of young people seeking the best opportunities for the development of their social capital. Interesting determinants have been observed, such as the size of the country. It turns out that student mobility is lower in larger countries which have numerous, internationally recognised courses on offer (e.g. the USA, UK) compared to smaller countries (e.g. Luxembourg) which cannot boast of such an offer. In the latter case, the outward mobility among young people is more pronounced (Kaczmarczyk, Okólski 2005: 79). Most importantly, wealthier countries have undertaken steps to attract international students through scholarship schemes, grants and special programmes as well as by establishing teams aimed at recruiting students from selected countries. These initiatives have been successful. The leaders of internationalisation of higher education in 2015 (Study 2017: 9) were New Zealand (21.14\%), the United Kingdom (18.49\%), Switzerland (17.8\%), Austria (15.89\%) and Australia (15.47\%) with an average of $8.38 \%$ across 25 countries. Poland ranked 24 th, with its $2.64 \%$ in terms of the internationalisation of higher education, ahead only of Chile $(0.31 \%)$. However, the rate increased, as previously as few as $1.1 \%$ of international students studied in Poland and, in Europe, we were ahead only of Croatia and Turkey (OECD Report 2008).

For at least a few decades now, the topic of international students has been raised in Polish scientific discourse. Initially, it did not refer to internationalisation and focused mainly on topics concerning the culture clash, the problem of "us" and "outsiders" in a student milieu, the motives for coming to Poland, and the problems of adaptation experienced by foreign students who often came from so-called "third-world countries" at the time (Nowicka, Łodziński 1993). It was not until a few years ago that the issue of university internationalisation, as one of the challenges faced by the global academic life, also became seminal in Poland (Żołędowski 2010; Hut, Jaroszewska 2012; Kawczyńska-Butrym 2014). The internationalisation of higher education is not only about attracting international students, but also concerns the internationalisation of researcher contacts and scientific research. The awareness that "internationalisation is the main driving 
force behind the development of higher education in the world is of the utmost importance". ${ }^{2}$ These contacts enable the exchange and development of intellectual capital based on cooperation between countries and universities. Intellectual capital does not only play a huge role in science. Drawing on the available body of academic literature, Tomasz Domański states that:

International education has become an important political tool for promoting China and its system of values and culture. It perfectly serves the purpose of the country's international expansion through the soft power mechanisms described by Joseph Nye Jr., alongside military and economic power (Nye 2002).

In conclusion, Domański stresses that international education "is an investment in the future, whose political, economic and cultural effects will become apparent later" (Domań ski 2017: 67). In addition, it is difficult to assess these effects in the short run.

The internationalisation of higher education was also discussed at the 2018 Conference of Rectors of Academic Schools in Poland which addressed the issue of international students in Poland. It was stated that "We already have about 72,000 foreign students and their number will probably reach 100,000 in 2020". ${ }^{3}$ This requires the advanced internationalisation of scientific research, and the continuous recruitment of students from many countries and on many continents. Medical universities have been very successful at this. However, this does not mean that medical universities should be the only hallmark of the internationalisation of higher education in Poland. Foreign students should also be offered non-medical courses and the range of courses offered in English should be expanded. It is also noteworthy that involvement of international students expands international contacts between countries and universities, bolsters their prestige in the international arena, and creates a platform for current and future scientific, economic and cultural cooperation between universities and countries. Moreover, the internationalisation of higher education is related to the growing need for the internationalisation of science. It is also associated with the challenge faced especially by the young generation of scientists who are encouraged to conduct scientific research that is strongly embedded in international research networks (Kwiek 2015: 21). Thus, the internationalisation of higher education can be seen as a platform for the development of the existing and future international networks.

\section{On destination countries}

The USA $(1,043,839$ foreign students), UK $(496,690)$, China $(397,635)$ and France $(309,642)$ are among the most popular destination countries chosen by international students in recent years. Out of the total of 4.6 million students studying

\footnotetext{
${ }^{2} \mathrm{http}: / /$ naukawpolsce.pap.pl/aktualnosci/news.28066gowin (accessed 1.03.2019).

${ }^{3}$ http://www.studyinpoland.pl/konferencja2018/ (accessed 15.10.2019).
} 
abroad, $25 \%$ studied in the USA, $12 \%$ in the UK and $10 \%$ in China. Foreign students came mainly from Asia (57\%), Europe (22\%) and Africa (11\%) (Study 2017: 10).

One cannot fully agree with the statement that "student migration is triggered by the mobility of participants, mainly students" (Grabowska 2013: 119). Obviously, students are the main actors in this migration process, and it is they who make decisions about studying abroad. The contemporary young generation treats education, including education abroad, as a long-term and indispensable investment in achieving success in life. It gives them a chance to increase their own social capital and subsequently improve their future quality of life. Apart from young people, there are many other actors and activities that stimulate student migration. Universities are interested in the influx of students not only for reasons of prestige. Given worldwide demographic changes and the ageing of some populations, there are signs indicating the importance of even a moderate influx of young people to higher education institutions, even when they do not stay for the entire calendar year there. This is important even when it comes to an influx of young people from the same country and from among national universities i.e. within the framework of internal student migration (Rokita-Poskart 2017). Financial considerations are also important, especially when it comes to international students. It turns out that a university's internationalisation generates additional funds for the university and has a positive effect on the economy of the city in which foreign youth study (Stróżek, Butrym 2014). International students spend money on food, hygiene items, accommodation and cultural events (Kubiciel-Lodzińska 2014). Another important economic factor is related to foreign students' access to various institutions and services including universities, healthcare, banks, restaurants, transport and others. In 2018, one of the dailies quoted a municipal official saying that "Lublin universities earn almost PLN 53 million a year thanks to international students. The city's economy earns another 80 million PLN" (Ćwieluch 2018). Revenues generated by foreign students are carefully estimated in many countries. It is estimated that, globally, profits exceed USD 100 billion a year. These profits are shared unevenly. They are the highest in the countries with the highest level of internationalisation. And these are universities in New Zealand, Australia and the United Kingdom, where the proportion of foreign students in the total number of students is over $18 \%$, which generates high profits. For example, Deloitte Access Economics estimates that "in 2014-2015, revenues related to international students' arrivals and stay in Australia reached USD 16.9 billion amounting to $1 \%$ of GDP; 128,000 jobs were created" (Fryc 2017). It is therefore clear that not only future economic development, but also the current material standing cannot be ignored when it comes to countries' efforts to expand the internationalisation of higher education.

However, it seems that "the fight for gifted youth" is most important since it has the most far-reaching consequences. National economies compete for intellectual capital, since intellectual advantages are translated into a stronger economic 
position in the future. And it is the main objective of efforts made to attract and then retain foreign students, thus acquiring human capital, including intellectual capital. An estimated 220,000 students from China will study in the UK in 2020, not to mention students from other countries (Asteris 2006, after: Matacz 2014: 38). Clearly, internationalisation is on the rise. "In 2014, the global population of internationally mobile students amounted to 5 million, but, according to OECD estimates, their number will reach 8 million by 2025" (Fryc 2017).

The competition for gifted youth is not only focused on attracting an influx of students from abroad. The countries where foreign students have been educated are interested in them staying there. Clearly, in the case of student migration both the country of origin and the destination country are concerned about their economic, social and cultural development, which largely depends on intellectual capital, or, more broadly, human capital and general social capital comprising people with diplomas and high professional competence. In the long run, destination countries are interested in retaining the most gifted international students, and they offer them opportunities to apply for $\mathrm{PhD}$ studies or obtain a greater range of specialisations. For the destination country, this is one of the forms of brain drain, an attempt to make gifted, creative and highly qualified graduates stay.

Brain drain mainly implies the outflow of high-performance professionals often attracted by more economically advanced countries, whereas brain gain mainly implies employment of professionals who make up for a shortage of specialists in a destination country. Brain drain provides an opportunity for destination countries to bridge the gap in certain economic sectors. Attracting international students can be seen as an opportunity to gain "valuable, highly-qualified employees to build the country's economic potential" (Matkowska 2010: 87). For this reason, destination countries, including Poland, are interested in graduates staying in the country that provided them with higher education. In the long run, they expect international students to fill an important segment of the labour market (Trzciński 2015: 205) and become an important component of the intellectual capital needed to build a knowledge-based economy. However, when graduates stay in the country they studied in, their outflow diminishes the economic potential of the country of origin (Balicki 2007: 232). The employment of international graduates in the destination country is a form of brain drain. Many countries use this approach to attract the human capital needed to build the knowledge society and develop the country in general. Japan is one example. In Japan, "Approximately 5,000 international graduates of the Japanese universities move directly from a student status to an employee status per annum" (Dzienis 2013: 8). Some international students (and this is especially true of young people from Ukraine and Belarus studying in Poland) see it as an opportunity to stay in a country with a generally higher standard of living, greater social and economic stability and better career prospects. In addition, it promotes a positive image of the country they study in and want to live in (Trzciński 2015: 208). 
What is Poland's situation in this context? And what is the situation of Ukraine, which is the country of origin of the largest number of foreign students in Poland?

\section{On international students in Poland}

The existing and planned level of internationalisation in Poland is not impressive when compared to other countries. To a certain extent, the enrolment of students from abroad has become a necessity for some faculties and some universities. For at least a decade now, Polish universities have been facing the problem of a population decline and a decreasing number of secondary school graduates. Due to the changing demographic structure, the number of young people willing to study at Polish higher education institutions has been decreasing each and every year. This is due to greater opportunities to study abroad and growing economic migration of young people after 2004, when Poland joined the European Union, thus enabling the free movement of people across borders.

Due to the decline in the number of young Poles who enrol at Polish universities, it might be necessary to cut the number of teaching hours, which would cause problems in maintaining employment of the existing academic staff. The Ministry of Higher Education and higher education institutions promote the internationalisation of higher education to keep the university staff and alleviate the negative consequences of the population decline that has resulted in the lower number of Polish students. In addition, the admission of international students contributes to the improvement of university's financial standing, as some foreign students pay relatively high tuition fees. At the end of the last century, it was estimated that revenues coming from educating international students significantly boosted the economies of destination countries (Siwińska 2007: 15; Siwińska 2014). For instance, in the UK, revenues generated due to educating international students amount to around $£ 20$ billion a year (Matacz 2014: 57).

The influx of students from abroad is indicative of the attractiveness of the educational and scientific opportunities offered by a given university. This is true of academic centres which offer courses at different faculties and in various fields in foreign languages. This attracts students with diverse interests and increases the number of young people who choose such a higher education institution. Rectors of Polish higher education institutions have recently discussed the internationalisation of higher education in Poland, and they have indicated that international students are attracted to Poland for the following reasons, among others:

It is safe in Poland. The cost of living is lower here than in Western Europe. The legal regulations concerning international students are also friendly: for example, a graduate of the Polish university can undertake employment without additional permits. The same goes for a fulltime student. University graduates can also obtain an annual residence permit in Poland in order to seek employment or travel (Fryc 2017). 
Previous studies conducted in Poland (Żołędowski 2010; Hut, Jaroszewska 2012; Kawczyńska-Butrym 2014) also show that, apart from university courses, there are other factors that attract international students to Poland. These are:

- relatively low tuition fees compared to those in the country of origin; this factor is acknowledged by many students from Western and Asian countries, most notably students of medicine;

- the small distance between the countries and low travel costs; this is appreciated especially by students from Ukraine and Belarus who often choose cities close to Poland's eastern border which are easily accessible from the student's country of origin and place of residence; nevertheless, Warsaw, Wrocław and other cities in central and western Poland are also popular among these students;

- the low cost of living (accommodation and meals), which is appreciated by all students, not only those from Eastern Europe;

- the ease of commuting to classes, which appears to be the motivation behind the decision of students from Ukraine to study in smaller towns.

Monika Grabowska interprets factors stimulating the growth of student migration in a broader way to include the perspective of governments and university authorities. The author lists the following factors which can boost student migration:

- student mobility,

- European educational initiatives, such as Erasmus and Socrates programmes,

- the new vision of governments, which see student migration as an opportunity to boost the intellectual potential of their country,

- the new vision of university authorities that are interested in enrolling international students and encouraging Polish students to study and undergo internships abroad (Grabowska 2013: 115).

However, the choice of a given country, university and course is determined by students' individual preferences. As mentioned above, relatively low tuition fees motivate many international students. Foreign students who decided to study in Gdańsk said they did so "because there are more favourable tuition fees and lower costs of living in Poland". These tuition fees would be considered by Polish students as high, since "A year at the Faculty of Medicine/ English Division costs PLN 43,000 (over EUR 10,000), and you have to pay PLN 23,000 (nearly EUR 5,500) at the Faculty of Nursing/ English Division" (Studenci 2016). These costs are clearly satisfactory for international students from different countries who declare that they find these tuition fees attractive and therefore study medicine at Polish universities. They often represent a separate group of international students who pay tuition fees in Poland, and they are of a higher economic status. This does not always resonate with Polish students (Kawczyńska-Butrym 2014). The fact that medical universities are the most internationalised encourages other universities to develop curricula attractive for international students. This is 
especially true of the universities and faculties whose graduates are ranked high. As stated at the Conference of Rectors: "It is time to start promoting IT courses. Since our students win prestigious competitions for software engineers, there is no reason why the Polish universities which run these top-notch courses should not win as well" (Fryc 2017). It should be added that medical universities have limited arguments for persuading foreign graduates to stay in Poland. This is determined both by students' legal obligations to their country of origin (e.g. a student loan obtained in a home country under certain conditions) and the financially unattractive job opportunities for healthcare practitioners in Poland compared to many other countries of origin (e.g. Norway). Otherwise, there are no formal obstacles that prevent them from staying in Poland.

\section{What do we know about students from Ukraine, their situation in Poland, and their post-graduation plans?}

Students from Ukraine have been a special and most numerous group of international students in Poland for several years. In the academic year 2004/2005, there were 1,989 students from Ukraine studying in Poland, their number reached 4,817 five years later and 30,589 ten years later. The most recent data from the Polish Central Statistical Office (GUS) indicate that 39,203 young people from Ukraine studied in Poland in 2018. This situation should be analysed against the backdrop of the events in Ukraine.

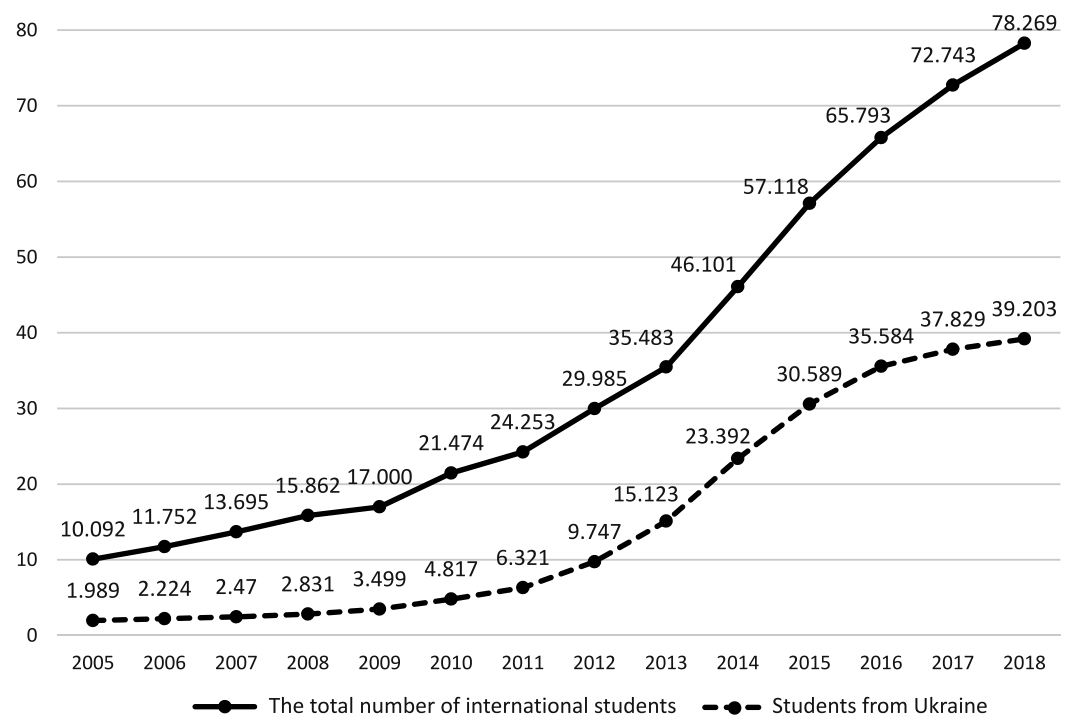

Figure 1. The number of students from Ukraine compared to the total number of international students in Poland (in thousands)

Source: GUS 2006-2019. 
International students decide to study in Poland for various reasons. Motives include favourable tuition fees and a relatively low cost of living compared to many Western countries. Some students show an interest in Poland as a country. Based on the analysis of student migration from Ukraine, it can be concluded that student mobility in this case can be seen as "as an escape from the home country rather than the process of exchange of ideas/knowledge accompanied by journeys and returns" (Kyvliuk, Svyrydenko 2017: 367, cited in: Andrejuk, Korniychuk 2018: 123). However, we should be aware of the situation in Ukraine, "three successive Ukrainian revolutions in the late 20th and early 21st centuries: the Revolution on Granite, Orange Revolution and Revolution of Dignity"4 (S okury anskaya, Svid 2019). We should also pay special attention to the ongoing war in Donbass which may have been the reason behind the increased influx of students from Ukraine observed in Poland in the last few years. The interpretation of Kyvliuk and Svyrydenko may be justified, since young people in Ukraine experience a lack of stability and their life is in danger.

From a Polish perspective, it is interesting to learn why students from Ukraine decide to study in Poland. The key factors are listed below:

- the cost of living is lower than in other countries (39\%),

- it is possible to study free of charge or with a partial fee waiver $(29 \%)$,

- it is easy to enrol (28\%) (Nowak 2018),

- you obtain a European diploma (Ćwieluch 2018).

There is yet another difference in the social and ethical context of studying in Poland as opposed to Ukraine which is often ignored. Namely, these are the formal and informal costs of studies. Although many Ukrainian students have to pay tuition fees in Poland, in Ukraine they would have to bear additional, hidden costs: "[...] when you count how much you have to spend on bribes for lecturers in Ukraine, it turns out that it is even cheaper to study in Poland" (Ćwieluch 2018).

There are other, slightly less influential factors that determine the choice of Polish universities, namely the positive opinion about the quality of education provided by the university $(22 \%)$ and faculty $(22 \%)$, the prospects of finding a job in Poland after graduation in line with one's major $(22 \%)$, as well as general employability not necessarily in line with one's major (12\%). The latter two motives indicate that the prospects of finding a job in Poland upon graduation play a significant role in making a decision about studying here. When addressing the question of post-graduation plans, as few as $28 \%$ of the students declare they would like to work in Poland, $29 \%$ plan to find employment in another EU country while $9 \%$ want to work in a non-EU country. As few as $8 \%$ plan to return to Ukraine (Nowak 2018).

4 The Revolution on Granite on the eve of the collapse of the USSR of October 7-17, 1990; the Orange Revolution from November 22, 2004 - January 23, 2005; and the Revolution of Dignity from November 21, 2013 - February 2014. 
Let us take a look at the findings of one of the studies that explored the situation of Ukrainian citizens including students in Poland. It turned out that more than one in two students combined studies and work (57\%) and every third declared a willingness to work (33\%). However, it should be added that only $36.5 \%$ of those working had regular employment, while as many as $63.5 \%$ had part-time jobs. They were mostly employed in trade (26.3\%), hotels and catering services (20\%). Only $16 \%$ of the students surveyed did not work and did not intend take up employment (Chmielewska, Dobroczek, Puzynkiewicz 2016: 28-29). It can be assumed that some students have to take up employment for financial reasons (tuition fees, especially at private universities, accommodation, meals and other). This is indicated by the fact that more than one in four Ukrainian students studying in Poland (28.7\%) stated that his/her income was the main means of subsistence in Poland (Chmielewska, Dobroczek, Puzynkiewicz 2016: 30). Meanwhile, research conducted among 198 students of the Medical University of Lviv showed that $20 \%$ of them worked, that is, fewer students than in Poland (Dorosh et al. 2013: 530). The difference can be explained either by the time that lapsed between the research in Lviv (2012/2013) and research in Poland (2017), or by greater job opportunities (including part-time and odd jobs) available to students in Polish academic centres compared to Ukrainian ones. There was also a study that compared the number of Ukrainian students of medicine that worked in Lviv and Polish students (226 students of medicine in Suwałki) who found employment in Poland. It was found that students' decisions about employment were determined mainly by their own assessment of their financial situation; $40 \%$ of the students who assessed their financial situation as poor earned a living whereas the remaining $60 \%$ were supported by their parents (Dorosh et al. 2013: 528). There are additional findings concerning students from Ukraine taking up employment during their studies which come from research into the situation of international students in the Opole Province. The findings indicate that only students from the countries from outside the EU, including Ukraine, take up employment to pay their tuition fees. As stated by the author of the research-based report, "none of the EU respondents mentioned personal gainful employment as a source of financing education" (KubicielLodzińska 2014: 144). Thus, we have indirect evidence of the existing differences in the financial status of international students in Poland, depending on their country of origin. Thus, it can be concluded that some of the students from Ukraine facing financial difficulties take up employment in order to continue their education.

As indicated by the research conducted in the Netherlands and quoted by Sabina Kubiciel-Lodzińska (2014: 144), "students who have found a job are more likely to settle in the host country". Thus, destination countries can recruit well-qualified employees among international graduates. Therefore, these countries are interested in creating conditions for graduates to stay and take up employment in the country where they received higher education, even during the period of studies. 
What are the plans of students from Ukraine as regards returning to their country of origin after graduation from higher education institutions in Poland?

As outlined in the first part of the paper, a university degree is an institutionally testified form of intellectual capital. It is important both for the individual and graduate's country of origin. Recent studies conducted in Poland among students from Ukraine show that a relatively large proportion of them $(36.6 \%)$ declare their willingness to settle in Poland, only a slightly smaller proportion $(32.5 \%)$ plan to maintain partial ties with Poland, more than one in five $(22 \%)$ wants to migrate to another country. Although $6.5 \%$ of respondents have not yet made up their mind, as few as $2.4 \%$ of the students surveyed state they want to return to Ukraine (Chmielewska, Dobroczek, Puzynkiewicz 2016: 30). A comparison of the results of both published studies may suggest that between 2016 and 2019 , the percentage of students declaring their willingness to return to Ukraine increased from $2.4 \%$ to $8 \%$. On the one hand, this should be considered beneficial for their country of origin, but, on the other, the difference in the number of respondents in both studies does not allow a definitive conclusion to be drawn. Rafal Trzciński's analyses do not justify generalisations either. Still, it can be concluded that a significant proportion of international students surveyed by him, especially those from Ukraine and Belarus, declared a desire to stay and work in Poland (Trzciński 2015).

\section{Concluding remarks}

From the perspective of international recommendations and declarations, higher education is conducive to the development of a knowledge society which, in turn, is beneficial for the social, economic and cultural development of a country. When addressing the issue of the benefits of the internationalisation of higher education, we may say that it is beneficial for everyone, that is students, the country of origin, and the destination country. It can be assumed that there are two sides of the coin, the interests (benefits) of the country international students study and stay in, and the interests (losses) of the country of origin abandoned by the students.

The analyses presented above show that students' destination countries gain more than their countries of origin. From the point of view of students' countries of origin, the fact that students do not return there means, in the short or long run, slower economic and social growth, delayed modernisation processes in many sectors of the economy and many areas of social and cultural life. This can therefore be perceived as a new form of brain drain used by countries which offer appealing curricula to international students and boost the internationalisation of their universities in order to attract intellectual capital. This is observed in many countries, which contradicts the fairly widespread opinion that young people from 
all over the world are migrating to other countries in order to acquire knowledge, but are then returning to their countries of origin in order to work there and "improve their social, cultural and economic situation" (Grabowska 2013: 117).

A review of literature on the internationalisation of higher education gives an outline of the global nature of student migration, its push and pull factors (Domański 2017), aspects related to the mobility of young people who wish to develop their social capital and achieve better employment prospects in the international and domestic labour market. And these are indisputable advantages of students studying abroad. As indicated by the results of international research, the internationalisation of higher education generates multi-faceted benefits (in terms of prestige and economic effects) for the university and the country that manages to attract an influx of international students. The example of Poland also proves that.

Undoubtedly, the Ukrainianisation of higher education in Poland has a positive effect on our country. It boosts the prestige of individual universities and generates profits due to the employment of Ukrainian graduates in our country. Apart from the financial contribution provided by students from Ukraine to the universities and cities they study in (Stróżek, Butrym 2014), they also compensate for the shortage of Polish students resulting from population decline. In other words, they support universities in a variety of ways. It is definitely in Poland's interest that this young, educated group of people settles in our country. Since young people from Ukraine constitute the largest number of international students in Poland, let me cite the following quote which illustrates the exchange that takes place in the area of higher education between Poland and Ukraine: "Ukraine gives Poland its most precious asset, its young people. And in return, we export to Ukraine the best of Poland, the European Union" (Ćwieluch 2018).

However, from the point of view of Ukraine as a country of origin, there may be justified fears that obtaining higher education in Poland becomes a step in the process of transferring social and intellectual capital from Ukraine. The capital is transferred not only to Poland, since many students declare that they are planning to move on, to work and live in other countries within or outside the European Union. Young people also leave Poland to study abroad. As Bohdan Rożnow ski (2014: 144) points out, "many of those who have left Poland may not return. This, in turn, may [...] significantly weaken the intellectual potential of Polish human resources".

When it comes to students from Ukraine, they find studies in Poland attractive in many ways. The overall economic and political situation in Ukraine is extremely complex at the moment, which can encourage young people to study abroad. In the long run, it may also be a decisive factor in their settling and finding employment in a destination country. It seems that only ensuring political stability in Ukraine will change the post-graduation plans of young people studying abroad and encourage them to return to their country of origin to boost its social, economic and cultural potential, as stipulated in the Bologna Declaration. If living conditions in Ukraine improve, it might suffer fewer losses as a result of student mobility. 
The issue under discussion can also be analysed from the perspective of young Polish people studying abroad. From this perspective, the importance of their return to Poland cannot be overestimated.

\section{Bibliography}

Andrejuk K., Korniychuk A. (2018), Ukraińscy absolwenci polskich uczelni: przechodzenie ze studiów na rynek pracy w kontekście samozatrudnienia, "Problemy Polityki Społecznej”, no. 40(1), pp. 121-140.

Asteris M. (2006), British universities: the "coal exporters" of the 21st century, "Journal of Studies in International Education”, no. 10, pp. 224-240.

Balicki J. (2007), Migracje i rozwój-aspekt globalny, "Biuletyn Rządowej Rady Ludnościowej", no. 52, Warszawa.

Bergen S. (2011), Internationalization of higher education: a perspective of European values, [in:] W. Martyniuk (ed.), Internacjonalizacja studiów wyższych, Fundacja Rozwoju Systemu Edukacji, Warszawa, pp. 11-27.

The Bologna Declaration of 19 June 1999. Joint declaration of the European Ministers of Education, p. 1.

Chmielewska I., Dobroczek G., Puzynkiewicz J. (2016), Obywatele Ukrainy pracujacy $w$ Polsce-raport z badania. Badanie zrealizowane w 2015 r., Departament Statystyki Narodowego Banku Polskiego, Warszawa.

Ć w i e 1 u c h J. (2018), Skąd nagle w polskich miastach tylu studentów z Ukrainy?, "Polityka", May 15 th.

Domański T. (2017), Internacjonalizacja polskich uczelni wyższych, [in:] T. Domański, A. Stępień-Kuczyńska, A. Włodarska-Frykowska (eds.), Internacjonalizacja polskich ośrodków politologicznych, Wydawnictwo Uniwersytetu Łódzkiego, Łódź, pp. 63-80.

Dorosh N., Boyko O., Kleszczewska E., Łogwiniuk K., Andryszczyk M. (2013), Porównanie nawyków żywieniowych studentów na Ukrainie $i w$ Polsce. Część I. Badania ankietowe, "Hygeia Public Health", vol. 48(4), pp. 526-535.

Dzienis A. (2013), Współczesne migracje w Japonii, "Biuletyn Migracyjny”, no. 44, p. 8.

Fryc J. (2017), Zagraniczni studenci szturmuja polskie uczelnie. To świetna wiadomość dla gospodarki, https://businessinsider.com.pl/technologie/nauka/studenci-zagraniczni-w-polscejak-wplywaja-na-gospodarke/2bsfvnr (accessed 21.04.2020).

Grabowska M. (2013), Migracja edukacyjna polskich studentów na tle trendów światowych, "Studia i Prace Wydziału Nauk Ekonomicznych i Zarządzania”, vol. 2(32), pp. 113-123.

Główny Urząd Statystyczny (GUS) (2006-2019), Higher education institutions and their finances in 2005-2018, Główny Urząd Statystyczny, Warszawa.

Hut P., Jaroszewska E. (2012), Studenci zagraniczni w Polsce na tle migracji edukacyjnych na świecie, Instytut Spraw Publicznych, Warszawa.

Kaczmarczyk P., Okólski M. (eds.) (2005), Migracje specjalistów wysokiej klasy w kontekście członkostwa Polski w Unii Europejskiej, Urząd Komitetu Integracji Europejskiej, Warszawa.

Kawczyńska-Butrym Z. (ed.) (2014), Migracje edukacyjne. Studenci zagraniczni-dwie strony księżyca, Wydawnictwo Uniwersytetu Marii Curie-Skłodowskiej, Lublin.

Konwencja o Prawach Dziecka z dnia 20 listopada 1989, Dz.U. z 1991 r. Nr 120, poz. 526.

Kubiciel-Lodzińska S. (2014), Studenci zagraniczni w Polsce - ich obecność na rynku pracy oraz wydatki (Na podstawie badań z województwa opolskiego), [in:] D. Kotlorz (ed.), Edukacje $w$ świetle przemian współczesnego rynku pracy, "Studia Ekonomiczne Uniwersytetu Ekonomicznego w Katowicach", no. 197, pp. 135-146. 
Kwiek M. (2015), Uniwersytet $w$ dobie przemian. Instytucje i kadra akademicka $w$ warunkach rosnacej konkurencji, Wydawnictwo Naukowe PWN, Warszawa.

Kyvliuk O., Svyrydenko D. (2017), Academic mobility as "brain drain" phenomenon of modern higher education, "Studia Warmińskie", no. 54, pp. 361-371.

Łukasiewicz G. (2009), Kapital ludzki organizacji, Wydawnictwo Naukowe PWN, Warszawa.

Matacz A. (2014), Studenci zagraniczni w Polsce $i w$ Lublinie - ich pochodzenie i rzeczywiste wybory kierunków ksztatcenia, [in:] Z. Kawczyńska-Butrym (ed.), Migracje edukacyjne. Studenci zagraniczni - dwie strony księżyca, Wydawnictwo Uniwersytetu Marii Curie-Skłodowskiej, Lublin, pp. 55-71.

Matkowska M. (2010), Sytuacja studentów cudzoziemców w Polsce, "Studia i Prace Wydziału Nauk Ekonomicznych i Zarządzania", no. 18, pp. 87-98.

Mendryk I., Kawczyńska-Butrym Z., Oleszko-Kurzyna B., Galbarczyk T. (2020), Gospodarstwa domowe z 500+ $w$ procesie rozwoju kapitalu ludzkiego. Wybrane problemy ekonomiczne i socjologiczne, Wydawnictwo C.H. Beck, Warszawa.

Nowak M.K. (2018), Ukraińskich studentów coraz więcej, a madrej polityki migracyjnej brak. Bo jakoś to będzie, https://oko.press/ministerstwo-ds-jakos-to-bedzie-ukrainskich-studentowcoraz-wiecej-spojnej-polityki-migracyjnej-brak/ (accessed 7.02.2019).

Nowicka E., Łodziński S. (1993), Gość w dom. Studenci z krajów Trzeciego Świata w Polsce, Oficyna Naukowa, Warszawa.

Nye J.S. Jr. (2002), The information revolution and American soft power, “Asia Pacific Review”, no. 9 , pp. 60-76.

OECD Report (2008), Higher Education to 2030 (Vol. 1): Demography, OECD Publishing.

Rokita-Poskart D. (2017), Migracje edukacyjne i ich demograficzne konsekwencje dla ośrodka akademickiego (na przykładzie miasta Opola), "Studia Ekonomiczne. Zeszyty Naukowe Uniwersytetu Ekonomicznego w Katowicach”, no. 309, pp. 85-94.

Rożnowski B. (2014), Strategie adaptacyjne studentów z Ukrainy: przykład lubelski, [in:] Z. Kawczyńska-Butrym (ed.), Migracje edukacyjne. Studenci zagraniczni - dwie strony księżyca, Wydawnictwo Uniwersytetu Marii Curie-Skłodowskiej, Lublin, pp. 141-154.

Saryusz-Wolski T., Piotrowska D. (2011), Internacjonalizacja: mobilność studentów, [in:] W. Martyniuk (ed.), Internacjonalizacja studiów wyższych, Fundacja Rozwoju Systemu Edukacji, Warszawa, pp. 43-55.

Siwińska B. (2007), Education goes global! Strategie internacjonalizacji szkolnictwa wyższego, Fundacja Edukacyjna "Perspektywy", Warszawa.

Siwińska B. (2014), Uniwersytet ponad granicami. Internacjonalizacja szkolnictwa wyższego $w$ Polsce $i$ w Niemczech, Dom Wydawniczy Elipsa, Warszawa.

Sokuryanskaya L., Svid O. (2019),Dynamika cinnisnych orijentacji ukrajins'kych studentiv czasiv nezalezhnosti: "nazad do materializmu”?, http://sg-sofia.com.ua/dinamika-zinnisnihorientazij-ukr-studentov-chasiv-nezaleznosti (accessed: 12.02.2020).

Stróżek A., Butrym M. (2014), Mieszkańcy Lublina o studentach zagranicznych, [in:] Z. Kawczyńska-Butrym (ed.), Migracje edukacyjne. Studenci zagraniczni-dwie strony księżyca, Wydawnictwo Uniwersytetu Marii Curie-Skłodowskiej, Lublin, pp. 189-200.

Studenci zagraniczni. Mamy ich coraz więcej. Dlaczego wybieraja nasze uczelnie? (2016), https://www.gdansk.pl/wiadomosci/studenci-zagraniczni-mamy-ich-coraz-wiecej-dlaczegowybieraja-nasze-uczelnie,a,62654 (accessed 16.05.2020).

Study in Poland. Studenci zagraniczni w Polsce 2016 (2017), Fundacja Edukacyjna "Perspektywy", Warszawa.

Trzciński R. (2015), Zagraniczni studenci - czy potencjalni uczestnicy polskiego rynku pracy, [in:] J. Konieczna-Sałamatin (ed.), Imigranci o wysokich kwalifikacjach na polskim rynku 
pracy. Raport z badań 2014-2015, Instytut Społeczno-Ekonomicznych Ekspertyz, Fundacja "Nasz Wybór", Warszawa, pp. 175-210.

Żołędowski C. (2010), Studenci zagraniczni w Polsce: motywy przyjazdu, ocena pobytu, plany na przyszłość, Wydawnictwa Uniwersytetu Warszawskiego, Warszawa.

\title{
UMIĘDZYNARODOWIENIE STUDIÓW WYŻSZYCH - DLA KOGO ZYSKI, DLA KOGO STRATY?
}

\begin{abstract}
Abstrakt. W międzynarodowych deklaracjach podkreśla się rolę wyższego wykształcenia w budowaniu społeczeństwa wiedzy i jego związek z rozwojem ekonomicznym, społecznym i kulturowym poszczególnych krajów. W artykule ukazano ekonomiczne znaczenie umiędzynarodowienia studiów dla rozwoju uczelni, miast i krajów, w których studiują zagraniczni studenci. Jednocześnie podkreślono, że jednym z czynników i form drenażu mózgów oraz walki o "mądre głowy” przez kraje zainteresowane własnym rozwojem staje się umiędzynarodowienie studiów wyższych i zatrzymanie części wykształconych studentów zagranicznych na swoim rynku pracy. Na przykładzie Polski, gdzie wśród studentów zagranicznych dominują studenci z Ukrainy, przedstawiono zyski kraju przyjmującego studentów i straty kraju ich pochodzenia. Uwzględniono przy tym aktualny kontekst braku politycznej stabilizacji na Ukrainie, co może dodatkowo, w większym stopniu niż w innych krajach, skłaniać młodych ludzi do wyjazdu na studia i braku planowanego powrotu do kraju pochodzenia.
\end{abstract}

Slowa kluczowe: umiędzynarodowienie studiów, studenci zagraniczni, przyjazdy studentów, plany studentów. 